\title{
KOMITE MADRASAH \\ Sebuah Telaah atas Hakikat dan Perannya dalam Peningkatan Kualitas Madrasah
}

\author{
Muhmidayeli
}

\begin{abstract}
Recently, madrasah as planned and systemized educational institution in its introduction is considered as less effective and mistarget. It is because of its introductive academic practices more prioritize achievement of cognitive domain, while affective and psychomotor domains are not touched well yet. Besides, it is also because of centralistic educational managerial aspect. In respect of such issues, internal restoration of madrasah may be held through two ways: instructional-academic and managerial academic. Madrasah committee as independent institution in educational system of madrasah is an institution that serves various needs required in educational process in order to be effective and efficient in holding its function and role as to grow the human resources quality that is core of social and national development.
\end{abstract}

Keywords: Madrasah committee, community, and educational quality.

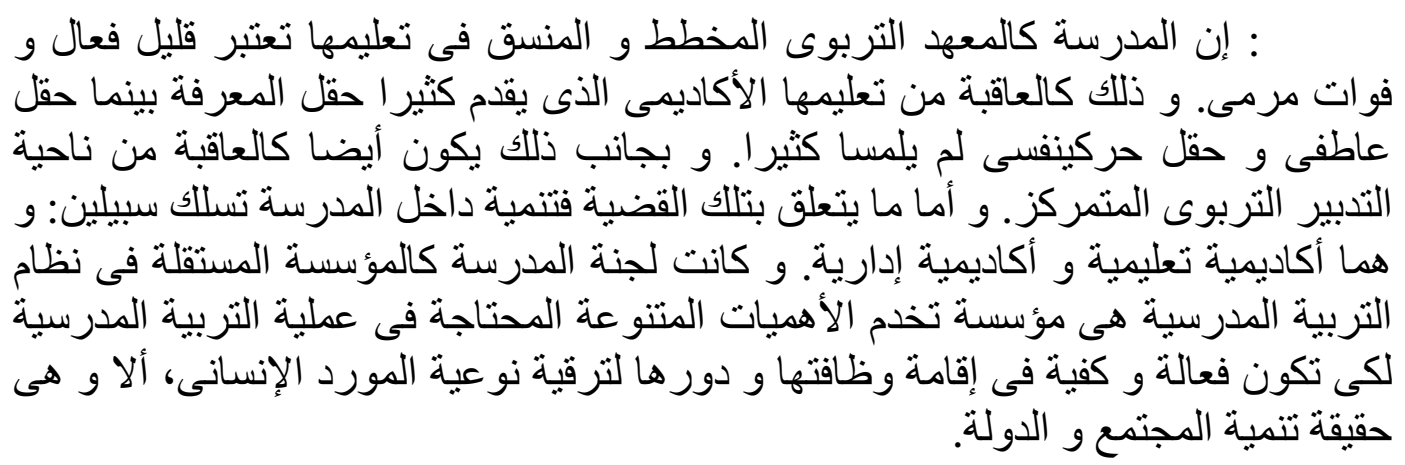

\section{I}

Hidup selalu berubah dan selalu menuju pada pembaharuanpembaharuan. Pendidikan persekolahan adalah alat sekaligus juga sebagai pembaharuan hidup, dan oleh karenanya sekolah/madrasah mestilah juga dilihat sebagai kebutuhan untuk hidup. Sebagai ujung tombak bangunan peradaban, fungsi sekolah selalu berhadapan dengan kebutuhan-kebutuhan pembangunan manusia dalam berbagai aspeknya. Kualitas sumber daya manusia banyak bertumpu pada kualitas sekolah. Persoalannya bukanlah entitas yang berdiri sendiri, karena ada banyak varian yang bergelayut di atasnya, baik dari subjek, maupun dari varian lain yang berada di luar dirinya.

Pembentukan dan penyempurnaan kualitas manusia dalam dunia persekolahan selalu berkenaan dengan persoalan proses pemanusiaan yang mengarah pada perbaikan dan kemajuan, sehingga dengan demikian dikatakan pula bahwa kemajuan suatu masyarakat sangat tergantung pada pola dan sistem yang ditempuh oleh suatu lembaga pendidikan dalam menggemleng subjeksubjek didiknya. Transformasi sosial tergantung pada orientasi, sistem dan 
strategi yang ditempuh lembaga pendidikan, utamanya pendidikan formal yang secara niscaya lebih terencana, terprogram dan tertata secara rapi ke arah tujuan yang diinginkan.

Madrasah atau sekolah sebagai lembaga pendidikan yang terencana dan tersistematisasi, dalam penyelenggaraan pembelajarannya akhir-akhir ini dianggap kurang efektif dan tidak tepat sasaran. Hal ini tidak saja dikarenakan praktik akademik pembelajarannya yang memang lebih mengutamakan pencapaian ranah kognitif, sementara ranah afektif dan psikomotor sebagai pinalitas tercapai tidaknya tujuan pendidikan yang belum tersentuh secara baik, tetapi juga segi manajerial pendidikan yang sentralistik yang tidak memberikan rongga gerak bagi sekolah untuk membuat kreasi dan aksi yang berpusat pada problem dan kebutuhannya.

Kompleksitas problem akademik dan manajerial seperti ini, akan semakin rumit lagi bila dikaitkan dengan kondisi kehidupan masyarakat saat ini yang memang sangat kompleks. Hal ini juga akan semakin memperberat tantangan pendidikan madrasah yang memang berorientasi tidak saja pada aspek kebutuhan fisiologis subjek didiknya tetapi juga bagaimana ia dapat mengimplementasikan nilai-nilai luhur agama dan keberagamaan sebagai pemenuhan kebutuhan ruhaninya yang memang menjadi karakteristik dan bahkan menjadi muara bagi semua gerak langkah aktivitasnya.

Diakui memang bahwa saat ini telah terjadi perubahan besar dalam kehidupan umat manusia, tidak saja dalam lapangan sosial budaya, sains dan teknologi, bahkan juga dalam lapangan agama. Khusus dalam lapangan ini, terlihat adanya perubahan apresiasi dan persepsi umat terhadap nilai-nilai agama. Agama dengan nilai-nilai dogmatis-imperatifnya yang telah diterima selama ini, pada saat ini, justru sangat terbuka kemungkinan-kemungkinan untuk dipertanyakan dan dikritisi. Bahkan hal ini tidak jarang pula bermuara pada penegasian dan pengabaian ajaran-ajaran agama dalam kehidupan keseharian umat. Kecenderungan "negatif" umat terhadap agama seperti ini, setidaknya merupakan salah satu imbas budaya moderen di era globalisasi dan informasi yang telah semakin kuat mempengaruhi sikap perilaku masyarakat.

Memang kemajuan sain dan teknologi telah membuat masyarakat menjadi lebih bersikap pragmatis, rasionalis dan kritis dalam segala aspek kehidupan yang dialaminya, bahkan nilai-nilai agama pun akan sangat terbuka dipertanyakan secara amat gampang dengan ukuran nilai kepraktisan dan kerasional-empirisannya.

Mengingat eksistensi pendidikan madrasah/sekolah selalu berkenaan dengan upaya sadar seseorang atau sekelompok orang yang ditujukan untuk pengembangan humanitas manusia yang menjadi subjek yang dididik agar ianya berkualitas seperti yang diinginkan, maka wajar jika kita lihat bahwa dalam perjalanan sejarah persekolahan dari sejak awal lahirnya selalu mengarah pada progresivitas dan transformativitas dalam kehidupan manusia, baik yang bernuansakan jasmani maupun ruhani. Konsekuensinya, pendidikan memuat sesuatu yang dibutuhkan manusia, tidak saja yang berdimensi pragmatis, tetapi juga idealis, tidak saja bercorakkan yang profan, tetapi juga yang sakral, tidak saja sarat dengan muatan pengetahuan, tetapi juga moral, baik untuk kepentingan individu maupun sosial, yang mencakup kepentingan kehidupan 
sekarang dan mendatang. Sedemikian rupa sehingga dapat dikatakan, bahwa esensi pendidikan sekolah tidak lain adalah perubahan ke arah yang lebih "baik". Dengan demikian berarti, bila tidak terjadi perubahan-perubahan sebagaimana yang diinginkan, sesuai dengan tujuan-tujuan yang telah digariskan oleh suatu lembaga pendidikan madrasah, sama artinya tidak ada pendidikan itu sendiri. Hal ini berarti pula, bahwa pendidikan madrasah mesti senantiasa sadar akan tugas pentingnya untuk membawa subjek-subjek didik ke arah yang telah ditetapkan. Segala aktivitasnya dan hal-hal yang berkenaan dengannya mesti pula ditata sedemikian rupa dalam rangka peraihan tujuantujuan yang telah digariskan.

Semakin derasnya perubahan-perubahan sosial sebagai akibat dari kemajuan ilmu pengetahuan dan teknologi, menjadikan tugas-tugas kependidikan di madrasah pun semakin berat, bahkan sebahagian ahli pendidikan Islam akhir-akhir ini merasa khawatir jangan-jangan pendidikan Islam dalam format yang tengah berlangsung saat ini tidak dapat menjawab pemenuhan kebutuhan humanitas manusia, baik sebagai makhluk individual dan sosial, maupun sebagai mu 'abbid, khalifah fi al-ardh dan 'imarah fi al-ardh.

Eksistensi madrasah sebagai lembaga pendidikan agama merupakan instrument strategis bagi pengisian dua kebutuhan dasar manusia seperti diungkap di atas. Dalam konteks seperti inilah keberadaan madrasah perlu didiskusikan kembali, sehingga benar-benar dapat memberi arti bagi kehidupan keagamaan dan moralitas yang memang merupakan orientasi pendiriannya.

Dalam menyelenggarakan misinya, madrasah tidak dapat bekerja sendiri tanpa masyarakat sebagai subjek sekagus objeknya. Pendidikan madrasah pada hakikatnya muncul dari masyarakat dan memang berdiri untuk masyarakat. Madrasah yang terasing dari masyarakatnya, tidak saja akan menjadikan dirinya yang akan terasing dari masyarakatnya, tetapi boleh jadi juga eksistensinya akan dianggap sebagai ancaman dan bahkan mungkin musuh yang mesti disisihkan atau barangkali boleh saja ditinggalkan dan disingkirkan. Tulisan ini terfokus pembahasannya tentang bagaimana hakikat dan fungsi komite madrasah sebagai wadah peningkatan kualitas madrasah.

Baik secara ontology, epistemology maupuin axiology, pendidikan sekolah/madrasah erat kaitannya dengan upaya-upaya sistematis dan terprogram yang dilakukan dalam rangka mengembangkan sumber daya manusia, sehingga perumusan arah bangunnya pun merujuk pada idealitas manusia yang tidak hanya berdimensi psikobiologis, tetapi juga psikososial, moral dan relijius.

Bila dikaitkan dengan kondisi kehidupan kontemporer saat ini di mana perubahan yang amat cepat telah melanda pada hampir di seluruh aspek kehidupan, sehingga tidak jarang menimbulkan kegoncangan dalam kehidupan masyarakat, termasuk goncangan dalam sikap keagamaan dan nilai moralitasnya, menjadikan posisi madrasah semakin dibutuhkan. Bila peranan madrasah sebagai lembaga yang akan memenuhi tuntutan jasmani dan ruhani 
anak manusia seperti digambarkan di atas dapat dilakukan dengan baik, maka keberadaannya akan sangat diinginkan oleh masyarakat dan mungkin akan senatiasa dirindukan oleh masyarakat.

Mengingat madrasah sebagai agen transformasi sosial yang secara niscaya akan melahirkan suatu peradaban baru yang mengacu pada perbaikan dan kemajuan, maka dalam berbagai aktivitasnya ia mesti menjadi bagian yang integral dengan masyarakatnya. Hal ini tidak dapat dielakkan terutama karena memang suatu kebudayaan lahir selalu berdasarkan pada pola adaptasi yang dilakukan oleh individu atau kelompok dengan lingkungan masyarakatnya. Apa pun yang dilakukan manusia dalam kehidupan kesehariannya selalu bekenaan dengan pembentukan kebudayaannya. Oleh karena itu, pendidikan secara efisiensi mesti mengacu pada kepentingan rekonstruksi masyarakat. Pendidikan mesti diarahkan untuk memampukan subjek-subjek didik membangun dunia bagi masyarakat melalui pendayagunaan kemampuan akal, indra dan intuisi, sehingga pendidikan harus menjadikan subjek didiknya yang mampu menggunakan ilmu pengetahuan yang diperolehnya sebagai wahana bagi perealisasian nilai-nilai spritual.

Pendidikan sebagai suatu lembaga masyarakat tentulah diarahkan pada upaya rekayasa sosial, sehingga segala aktivitasnya pun senantiasa merupakan solusi bagi berbagai problem kehidupan dalam masyarakat. Sekolah dalam hal ini menjadi agen perubahan sosial, politik dan ekonomi yang primer. Oleh karena itu, lembaga pendidikan mesti memiliki komitmen untuk menciptakan masyarakat baru yang sarat dengan nilai-nilai dasar budaya dan sosial ekonomi yang akan membentuk harmonisasi suatu masyarakat. Pendidikan dalam hal ini mesti diarahkan pada perubahan pola pikir masyarakat, sehingga teknologiteknologi yang begitu besar lebih dijadikan sebagai sumber kreativitas dari pada untuk menghancurkan. Transformasi sosial merupakan suatu keniscayaan dan ini hanya dapat dilakukan melalui pendidikan. ${ }^{1}$ John Dewey (1859-1952 M) dalam hal ini mengatakan, bahwa education as recontruction. ${ }^{2}$

Pendidikan sekolah ataupun madrasah pada hakikatnya adalah usaha sadar bersama setiap individu terkait yang secara fungsional struktural melaksanakan tugas-tugasnya menuju terciptanya manusia-manusia ideal, yakni manusia yang memiliki kepribadian moralis, baik fungsinya sebagai mu abbid, khalifah fi al-ardh dan 'immarah fi al-ardh. Mengingat pendidikan adalah tugas bersama manusia dalam merealisasikan misi kemanusiaan seperti ini, maka sudah selayiknya pula pendidikan madrasah diatur berdasarkan hubungan intersubjektif dan interrelasional, sehingga semua komponen benar-benar berjalan secara fungsional struktural dalam kerangka yang jelas dan terarah pada peraihan tujuan-tujuan yang diinginkan.

Madrasah sebagai lembaga pendidikan agama pada hakikatnya berdiri atas dasar tuntutan masyarakat dan oleh karena itu sudah semestinya pulalah bagian terpenting dari tanggungjawab masyarakat. Dan karena memang ia hadir untuk masyarakat tentunya mesti dapat memainkan peranannya secara baik dalam memberikan solusi terhadap berbagai macam problematika yang muncul dalam masyarakat. Hal ini sangat penting agar eksistensi madrasah benar-benar semakin dipercayai oleh masyarakat, terutama dalam fungsinya sebagai wadah 
yang akan memberikan jawaban atas persoalan-persoalan dan kebutuhankebutuhan masyarakat dalam pembentukan dan pengembangan peradabannya.

Berdasarkan akan betapa pentingnya keberadaan madrasah seperti dipaparkan di atas, menjadikan madrasah untuk masa sekarang dan ke depan perananya tidak lagi sebatas sebagai lembaga pelengkap dan atau second education setelah tidak dapat diterima di sekolah-sekolah lain. Madrasah adalah agen perubahan yang memiliki arti strategis bagi pembangunan suatu masyarakat dan oleh karenanya ia mesti dikelola secara baik dan terprogram secara bersama-sama antar berbagai komponen lapisan masyarakat. .

Pendidikan madrasah yang memang diorientasikan pada nilai-nilai moral dan agama merupakan suatu kebutuhan dan memiliki urgensi bagi penumbuhkembangan perilaku moral senyatanya pada subjek didik. Membangkitkan nilai-nilai moral sebagai motivasi dalam segala aktivitas pendidikan dalam hal ini adalah suatu kemestian. Hal ini tidak saja mengingat bahwa upaya pendidikannya selalu mengarah pada perbaikan dan perubahan, tetapi lebih dari itu adalah bahwa pendidikannya bersentuhan langsung dengan penumbuh-kembangan moralitas yang tidak lain adalah suatu hal yang esensial bagi humanitas manusia.

Konsekuensi dari fungsi dan tugasnya seperti ini, maka dalam pengembangan kemampuan memahami suatu ilmu pengetahuan semestinya pula diiringi dengan kemampuan pengapresiasian nilai-nilai moral yang ada dalam ilmu pengetahuan tersebut. Dalam konteks evaluasi pembelajaran pun selain dievaluasi kemampuan memahami suatu ilmu tidak hanya diukur dari seberapa jauh kemampuan memahami dan menguasai ilmu pengetahuan tertentu, tetapi mesti juga diiringi dengan mengapresiasikan nilai-nilai moral yang ada dalam ilmu tersebut dalam tindakan nyata. Tegasnya saat ini sekolah tidak lagi hanya melahirkan orang pintar yang menguasai disiplin ilmu pengetahaun, tetapi mampu melahirkan orang yang cerdas dan brilian dalam mengapresiasikan nilai-nilai moral dari ilmu pengetahuan yang dimilikinya sehingga teraktualisasi ke dalam perilaku moral yang terpuji.

Tantangan dan problem pendidikan madrasah seperti ini memestikannya menata diri dalam rangka memberikan pelayanan yang baik tidak saja bagi kepentingan misi keagamaannya, tetapi juga mesti peka atas realitas problematika moralitas dan kebutuhan masyarakat dalam menghadapi tantangan kehidupan yang mungkin muncul setiap saat.

Pembenahan diri dalam pelayanan yang dimaksud di sini lebih berbentuk rekonstruksi terhadap aspek-aspek yang dianggap paling memungkinkan terrealisasinya peran madrasah sebagai lembaga masyarakat sebagaimana yang diinginkan di atas. Untuk maksud ini paling tidak pembenahan tersebut meliputi dua jalur yakni; akademik-pembelajaran dan akademik-manejerial. Jalur pertama ditujukan untuk membenahi proses yang berkenaan dengan peningkatan kualitas out put termasuk di dalamnya segala hal yang menyangkut media dan teknologi pendukung yang langsung membantu proses pembelajaran di madrasah.

Kecuali itu, pembenahan dapat pula diarahkan pada penertiban administrasi sekolah. Sedemikian rupa sehingga sekolah benar-benar terlaksana dengan penuh semangat kedisiplinan yang tinggi melalui planing yang jelas dan 
koordinasi yang terarah. Penertiban administrasi sekolah ini tidak saja meliputi peningkatan kualitas pengelola sekolah, tetapi juga pada siswa, sehingga sekolah senantiasa mengetahui perkembangan kualitas dan kuantitas pengelola dan sisiwa-siswanya. Hanya dengan cara pengelolaan kesiswaan, pengelola kependidikan dapat mencari upaya-upaya peningkatan dan pembenahan menuju sesuatu yang lebih baik.

Sehubungan hal di atas, pembenahan dalam diri madrasah mutlak dilakukan pada dua jalur, yakni akademik-pembelajaran dan akademikmanajerial. Melalui pembenahan dua jalur ini lah, tidak berlebihan untuk dikatakan, keberadaan madrasah diperlukan dan memang dibutuhkan. Hal ini sangat urgen, terutama karena berkaitan langsung dengan efektivitas aktivitas kependidikan di sekolah. ${ }^{3}$

\section{III}

Mengingat madrasah adalah lembaga pendidikan agama dari dan untuk masyarakat seperti disinggung di atas, menjadikan jalinan kerjasama yang baik antara sekolah dan masyarakat menjadi penting. Dan karena memang problem kependidikan selalu meliputi banyak varian yang terkait, menjadikan pimpinan madrasah tidak mungkin bekerja sendiri dan atau dengan guru saja. Sekolah memerlukan jalinan kerjasama dengan berbagai komponen yang dilakukan semestinya tidak saja dalam hal partisipasi penyediaan dana pendidikan saja seperti yang dipahami kebanyakan orang, tetapi lebih dari itu, bahwa masyarakat dilibatkan dalam berbagai suasana yang akan menghasilkan kualitas pendidikan yang menjadi harapan bersama, keluarga, sekolah dan masyarakat. Perubahan paradigma manajemen pendidikan dari sentralistik ke desentralistik menjadikan peluang kerjasama keluarga, sekolah dan masyarakat ini akan lebih mudah terwujud. Yang terpenting di sini adalah bagaimana menciptakan situasi yang kondusif untuk terciptanya suasana hubungan ini berjalan dengan harmonis. Untuk itu dibutuhkan suasana komunikatif yang tinggi antara ketiga komponen ini, karena memang tanpa itu, hubungan kerjasama akan menjadi tinggal lambang atan atau omong kosong belaka.

Keniscayaan harmonisasi hubungan keluarga, sekolah dan masyarakat seperti ini tidak saja karena ketiga unsur ini sama-sama memiliki kepentingan terhadap jalannya proses pendidikan, tetapi lebih dari itu di mana ketiga unsur ini sama-sama bertanggungjawab atas jalannya proses itu. Dan oleh karena itu pulalah, maka keterlibatan ketiga unsur ini mestilah disertai dengan keterlibatan mental dan emosional, riil dan bertanggungjawab.

Keaktifan masyarakat dalam mendukung proses kependidikan di sekolah ini, tidak saja mengingat sekolah adalah wadah transformasi sosial dalam berbagai varian, tetapi juga disebabkan oleh karena sekolah akan dapat menjawab keinginan dan tuntutan masyarakat. Keaktifan ini akan dapat membuahkan berbagai pengetahuan, pemahaman, keterampilan dan sikap bagi masyarakat yang secara niscaya tentu akan membentuk pola pikir dan gaya hidup yang merupakan lambang bagi suatu transformasi sosial. oleh karena itu, sudah sepantasnya masyarakat sebagai pengguna produk kependidikan sekolah 
turut berpartisifasi dalam membina dan memperlancar proses kependidikan di sekolah agar ianya efektif dalam fungsi dan tugasnya. Kualitas pendidikan di sekolah, pada prinsipnya adalah tanggungjawab bersama anggota masyarakat dalam berbagai lapisan. ${ }^{4}$

Hal ini semakin kuat pula denganm adanya P.P No. 39 tahun 1992 bab 2 pasal 2 yang menyatakan, bahwa partisipasi masyarakat dengan mendayagunakan segala kekuatan potensialnya sangat dibutuhkan dalam rangka menciptakan, memelihara dan meningkatkan kualitas pendidikan. ${ }^{5}$ Berdasarkan ini pulalah dituntut adanya saling keterbukaan antar komponen agar permaslahan hakiki mencuat dan pemecahannya pun akan mudah dilakukan.

Masyarakat sebagai pendamping personil kependidikan di sekolah, dapat menunjukkan partisipasinya dalam bentuk aktivitas-aktivitas sebagaimana yang diungkap dalam pasal 4 bab 3 P.P no. 39 tahun 1992 sebagai berikut:

1. Pendirian dan penyelenggaraan satuan pendidikan pada jalur pendidikan sekolah atau jalur pendidikan luar sekolah pada semua jenjang pendidikan kecuali pendidikan kedinasan.

2. pengadaan dan pemberian tenaga pendidikan

3. bantuan tenaga ahli

4. pengadaan dana dan pemberian bantuan yang dapat berupa wakaf, hibah, sumbangan pinjaman, beasiswa dan bentuk-bentuk lain sejenis

5. pengadaan atau penyelenggaraan program pendidikan yang belum diselenggarakan oleh pemerintah

6. pengadaan dan bantuan buku pelajaran dan peralatan pendidikan untuk kegiatan belajar mengajar

7. memberikan kesempatan magang atau latihan kerja

8. memberikan bantuan ruangan gedung dan tanah untuk belajar mengajar

9. bantuan manajemen bagi penyelengaraan satuan pendidikan dan pengembangan pendidikan nasional

10. memberikan bantuan pemikiran dan pertimbangan berkenaan dengan penentuan kebijaksanaan atau penyelenggaraan pembangunan pendidikan

11. memberikan bantuan dan kerjasama dengan kegiatan penelitian dan pengembangan pendidikan

12. keikutsertaan dalam program pendidikan atau penelitian yang diselenggarakan oleh pemerintah di dalam atau di luar negeri.

Komite madrasah adalah suatu organisasi independen dalam lingkup suatu sistem dalam sistem persekolahan yang bertugas mencarikan solusi atas berbagai problem kependidikan yang terkait dengan upaya-upaya yang layik untuk dilakukan dalam proses peningkatan kualitas sekolah agar menjadi sekolah yang unggul dalam berbagai aspek yang berkenaan dengan kependidikan. Komite madrasah pada prinsipnya didasari pada teori yang mengatakan bahwa sekolah tidak lain adalah bagian yang tidak terlepaskan dari unsur penting lainnya dalam masyarakat. Oleh karena itu, apa pun yang dilakukan sekolah mestilah dari dan untuk masyarakat, sehingga melibatkan masyarakat dalam memikirkan persoalaan kependididkan merupakan suatu keniscayaan, seperti yang telah disinggung di depan. 
Dalam konteks MBS, paling tidak ada tiga hal yang mendasar untuk diperhatikan oleh madrasah, yaitu:

a. ketergantungan madrasah pada pihak luar. ketergantungan ini memang tidak dapat dielakkan terutama ketika madrasah menerapkan manajemen berbasis sekolah. Hal yang perlu dicatat adalah bagaimana ketergantungan ini jangan sampai menjadikannya menghambat kreativitas dan inovasi dalam diri madrasah itu sendiri, sehingga madrasah tidak lagi sebagi objek kepentingan orang perorang atau kelompok tertentu yang akan menjadikan madrasah kehilangan jati dirinya sebagai lembaga pendidikan agama.

b. Madrasah biasanya terkait dengan yayasan tertentu yang secara niscaya tentu terikat pula dengan kultur dan birokrasi yang sentralistik dengan yayasan tersebut. Madrasah yang pada umumnya adalah dikelola oleh swasta yang berkonotasi sentralistik menjadikan madrasah sulit mengharapkan guru dan elemen lainnya untuk mengambil inisiatif yang inovatif dalam mengembangkan madrasah. Situasi ini secara deametral bertolak belakang dengan fungsi dasar MBS, karena dalam sistem MBS menghendaki keterlibatan penuh semua elemen masyarakat madrasah untuk menciptakan suasana kolaboratif dan kolektif yang tanpanya MBS tidak akan memberikan makna hakikinya.

c. Pengelola madrasah yang umumnya kurang memahami secara baik peran dan fungsi secara nyata, pada hal peran pimpinan madrasah adalah juga bagaimana memaksimalkan potensi masyarakat dalam meningkatkan kualitas madrasah. Inti penting dari kepemimpinan kepala sekolah adalah bagaimana mengoptimalkan semua elemen terkait agar fungsional dalam mewujudkan visi dan misi madrasah secara baik guna melahirkan madrasah yang berkualitas. ${ }^{6}$

Dari tiga hal di atas, dapat dilihat bahwa komite sekolah merupakan sesuatu yang sangat penting, karena melalui komite ini dapat dibangun sinergi antara pengelola madrasah dengan masyarakat dengan berbagai unsur dan pemerintah sehingga terbangun tanggungjawab bersama dalam membangun madrasah dalam hubungan yang interdepensi madrasah dan masyarakat sebagai stakeholders.

\section{IV}

Persoalan yang sering muncul kemudian adalah anggapan yang menyebutkan bahwa komite madrasah mestilah terdiri dari orang tua siswa karena memang eksistensinya berhubungan langsung dengan kepentingan mereka. Hal ini lumrah terjadi di negara-negara berkembang seperti Indonesia, karena masih dangkalnya pemahaman masyarakat akan arti pentingnya suatu lembaga pendidikan bagi kepentingannya. Ini semakin ditunjang pula oleh karena kondisi sosial ekonomi yang masih rendah yang akan menjadikan perhatiannya tertuju semata-mata untuk sektor ini. ${ }^{7}$

Asumsi seperti ini muncul, mengingat hukum kausalitas yang dimunculkan akibat proses yang dilakukan sekolah yang secara nyata terlihat 
bahwa pengguna jasa pendidikan madrasah seolah-olah orang tua saja. Pada hal, komite madrasah bukanlah suatu badan organisasi penunjang efektivitas proses akademik dan hal lain yang bergelayut di dalamnya saja, tetapi lebih dari itu, meliputi segala aspek yang akan menyokong terwujudnya realisasi tujuan-tujuan yang telah digariskan dengan standar yang optimal. Oleh karena itu, komite madrasah mestilah terdiri dari orang-orang yang memiliki rasa tanggung jawab yang tinggi atas keberlangsungan proses kependidikan di sekolah dan ianya memang mengerti dan memiliki kompetensi dalam dan dengan persoalan kependidikan.

Sebagai suatu bentuk badan partisipasi masyarakat yang peduli dan legal dalam tanggung jawab kemajuan proses pendidikan persekolahan, komite madrasah di samping sebagai wadah perantara sekolah dan masyarakat, komite madrasah juga turut bertanggung jawab atas efektivitas dan efisiensi pelaksanaan tugas-tugas kependidikan sekolah. Hal ini berarti, bahwa komite sekolah tidak saja berfungsi sebagai penyedia dana seperti dipahami umum, namun sesungguhnya lebih dari itu, bahwa ia mesti juga dilibatkan dalam proses pengambilan keputusan, baik dalam aspek perencanaan, penyelenggaraan program, perolehan manfaat, bahkan evaluasi dan pengendalian program madrasah. Pendeknya, komite madrasah pada prinsipnya adalah wujud kepedulian semua anggota masyarakat akan kualitas pendidikan, sekaligus juga menunjukkan kesadaran masyarakat akan arti pentingnya pendidikan persekolahan sebagai wahana transformasi sosial dalam berbagai bidangnya, seperti politik, ekonomi, hukum dan sebagainya. Kesadaran masyarakat akan makna pendidikan ini adalah akar tunggang bagi pembangunan peradaban manusia yang tentu juga akan mempercepat lahirnya masyarakat madani yang diidamkan semua orang.

Berdasarkan hal di atas, optimalisasi fungsi komite madrasah sesungguhnya merupakan kebutuhan yang tidak dapat ditawar-tawar dalam rangka peningkatan kualitas pendidikan madrasah. Hal ini tidak saja karena sekolah merupakan bagian yang tidak terlepaskan dari keluarga dan masyarakat seperti yang telah dijelaskan di muka, tetapi lebih dari itu bahwa perjalanan proses pendidikannya mesti dipikirkan dan diaktualisasikan secara profesional agar eksistensi madrasah benar-benar dapat menjawab persoalan masyarakat, dan ia pun tidak terasing bagi masyarakat pemiliknya.

Adapun tugas dan fungsi komite madarasah ini secara rinci dimuat pata bab7 pasal 7 keputusan dirjen kelembagaan agama Islam No: D.j. II/409/2003 sebagai berikut:

1. menyelenggarakan rapat-rapat komite sesuai program yang ditetapkan;

2. bersama-sama madrasah merumuskan dan menetapkan visi dan misi

3. bersama-sama madrasah menyusun standar pelayanan pembelajaran di madrasah

4. bersama-sama madrasah menyusun rencana strategis pengembangan madrasah

5. bersama-sama madrasah menyusun dan menetapkan rencana program madrasah tahunan, termasuk RAPBM 
6. membahas dan turut menetapkan pemberian tambahan kesejahteraan berupa uang honorarium yang diperoleh dari masyarakat kepada kepala madrasah, tenaga pendidik dan tenaga kependidikan madrasah

7. bersama-sama madrasah mengembangkan potensi ke arah prestasi unggulan baik akademis maupun yang bersifat non akademis

8. menghiompun dan menggali sumber dana untuk meningkatkan kualitas madrasah

9. mengelola kontribusi masyarakat berupa yang diberikan pada madrasah

10. mengelola kontribusi masyarakat berupa non material kepada madrasah

11. mengevaluasi program madrasah secara proporsional sesuai kesepakatan dengan pihak madrasah meliputi pengawasan, penggunaan sarana dan prasarana, pengawasan dan penggunaan keuangan secara berkala dan berkesenambungan

12. mengidentifikasi berbagai permasalahan dan memecahkannya besamasama dengan pihak madrasah

13. memberi respon terhadap kurikulumyang dikembangkan secara tersdandar nasional maupun lokal

14. memberikan motivasi, penghargaan material maupun non material kepada tenaga kependidikan atau kepada orang berjasa pada madrasah secara proporsional sesuai dengan kaedah profesional pendidik atau tenaga kependidxikan madrasah

15. memberikan otonomi profesional kepada pendidik mata pelajaran dalam melaksanakan tugas-tugas pendidikannya sesuai dengan kaedah kompetensi guru

16. membangun kerjasama dengan pihak luar yang bertujuan untuk meningkatkan kualitas pelayanan proses dan hasil pendidikan.

17. memantau kualitas proses pelayanan dan hasil pendidikan di madrasah

18. mengkaji laporan pertanggung jawaban pelaksanaan program yang dikonsultasikan oleh kepada madrasah

19. menyampaikan usul kepada pemerintah daerah untuk meningkatkan pelayanan pendidikan sesuai dengan kebutuhan madrasah. ${ }^{8}$

Dapat disimpulkan bahwa komite madrasah tidak saja berperan sebagai penunjang pembiayaan pendidikan di sekolah, tetapi juga meliputi segala persoalan yang berhubungan langsung atau tidak pada kualitas perolehan produknya, termasuk masalah perencanaan dan evaluasi pendidikan itu sendiri.

Dari tugas dan fungsi komite sekolah di atas tercermin tuntutan yang sangat serius dalam bekerja serta peka terhadap dinamika sosial masyarakat dan mampu membuat antisifasi kondisi mendatang. Jika komite madrasah memang terdiri dari orang-orang yang memiliki komitmen kuat terhadap kemajuan pendidikan madrasah dalam segala aspeknya baik akademis maupun non akademis, tentulah ia akan berfungsi sebagai badan yang benar-benar peduli dengan kemajuan pendidikan sekolah, bahkan ia juga berperan aktif dalam keseluruhan gerak kemajuan pendidikan madrasah itu sendiri. 
Lahirnya sekolah dan madrasah secara filosofis dan historis tidak lain adalah untuk menjawab kebutuhan masyarakat. Dan oleh karena itu, eksistensinya tidak dapat dilepaskan dari masyarakat. Masyarakat mestilah menjadi bagian terdepan dalam menyokong segala sesuatu yang berhubungan dengan penyelenggaraan madrasah. Oleh karena itu hubungan interdependensi keluarga, sekolah dan masyarakat tidak dapat dielakkan begitu saja jika menginginkan madrasah tidak terasing bagi pemiliknya, yaitu masyarakat. Dan masyarakat mestilah pula bertanggungjawab atas keberlangsungan aktivitas pembelajaran di madrasah.

Komite madrasah sebagai lembaga independen dalam sistem pendidikan madrasah merupakan lembaga yang mewadahi berbagai kepentingan yang dibutuhkan dalam proses pendidikan madrasah agar efektif dan efisien dalam menjalankan fungsi dan perannya sebagai penumbuhkembangan kualitas sumber daya manusia yang tidak lain adalah inti bagi pembangunan masyarakat dan negara yang tidak terelakkan.

Peranan komite madrasah ini bukan saja dalam penyediaan dana dan unsur materi lainnya, tetapi lebih dari, meliputi segala sesuatu yang berkenaan dengan berbagai persoalan yang berhubungan dengan kualitas penyelenggaraan proses kependidikan di madrasah.

\section{Catatan Akhir:}

${ }^{1}$ George F. Kneller, Introduction To The Philosophy of Education, Second Edition, John Wiley \& Sons, Inc, New York, 1971, h. 47. Lihat juga Arthur K. Ellis dkk., Introduction To The Foundations of Education, Prentice Hall, New Jersey, 1986, h. 122.

${ }^{2}$ Zuhairini dkk., Filsafat Pendidikan Islam, Bumi Aksara, Jakarta, 1992, h. 29.

${ }^{3}$ Uraian lebih lanjut, dapat dilihat tulisan Jup Schlerens, Peningkatan Mutu Sekolah, Logos, Jakarta, 1999, h. 25.

${ }^{4}$ Dapat dilihat umpamanya E. Mulyasa, Menjadi Kepala Sekolah Profesional, Rosda Karya, Bandung, 1998, h. 170.

${ }^{5}$ Lihat Undang-Undang RI, tentang Sistem Pendidikan Nasional, Sinar Graha, Jakarta, 1992, h. 290.

${ }^{6}$ Uraian yang lebih rinci dapat dibaca lebih lanjut, Dep. Agama RI., Pedoman Komite Madrasah, Dirjen Bimbaga Islam, Jakarta, 2003.

${ }^{7}$ Made Pidarta, Manajemen Pendidikan Indonesia, Rinneka Cipta, Jakarta, 2004, h. 185.

${ }^{8}$ Uraian lebih rinci dapat dilihat Depag RI., Pedoman Komite Madrasah, Dirjen Bimbaga Islam, Jakarta, 2003. 